\title{
Centromere protein $b$-null mice display decreasing reproductive performance through successive generations of breeding due to diminishing endometrial glands
}

\author{
K J Fowler ${ }^{1,2}$, L H Wong ${ }^{1}$, B K Griffiths ${ }^{1}$, M C Sibson ${ }^{1}$, S Reed ${ }^{3}$ and K H A Choo ${ }^{1,2}$ \\ ${ }^{1}$ Murdoch Childrens Research Institute, Royal Children's Hospital, Flemington Road, Parkville, Victoria 3052, \\ Australia, ${ }^{2}$ Department of Paediatrics, University of Melbourne, Australia and ${ }^{3}$ DAKO Australia, 12 Lord Street, \\ Botany, NSW 2019, Australia \\ Correspondence should be addressed to KJ Fowler; Email: kerry.fowler@mcri.edu.au
}

\begin{abstract}
Centromere protein B is a highly conserved constitutive protein found at centromeres. Gene knockout studies in mice have unexpectedly identified Cenpb as a candidate gene involved in uterine function. The present study further explores the role of Cenpb in mice by intermating Cenpb-null mice over several generations. Breeding studies and analysis of uterine tissue indicate that $C e n p b$-null mice lose reproductive fitness over a number of generations due to a significant reduction in endometrial glands. These results suggest that Cenpb may play an important function in the short- and long-term maintenance of uterine integrity.

Reproduction (2004) 127 367-377
\end{abstract}

\section{Introduction}

The mammalian centromere is the primary constriction in the dividing chromosome and is responsible for the accurate segregation of chromosomes during meiosis and mitosis. The centromere is made up of repetitive DNA enveloped by a specialised proteinaceous structure known as the kinetochore (Maney et al. 1999). Human centromere protein B (CENP-B) has been identified as an extraordinarily conserved $80 \mathrm{kDa}$ protein, which is distributed throughout the centromeric heterochromatin beneath the inner plate of the kinetochore throughout the cell cycle (Earnshaw et al. 1987, Cooke et al. 1990, Sullivan \& Glass 1991, Maney et al. 1999, Saffery et al. 1999). Sequence analysis has shown that the $\mathrm{N}$-terminus of CENP-B encodes a DNA-binding domain whereas the C-terminus of CENP-B houses the CENP-B dimerisation domain (Maney et al. 1999). CENP-B binds to $\alpha$-satellite DNA in man or minor satellite in mouse via a $17 \mathrm{bp}$ sequence known as the CENP-B box motif. These dual properties of CENP-B suggest that this protein organises the assembly of repetitive DNA at the primary constriction, facilitating centromere/kinetochore formation (Yoda et al. 1992).

The role of CENP-B in centromere biology has been controversial for many years, early studies in cell culture suggesting that it is an indispensable protein (Bernat et al. 1990, 1991). Recent studies in fission yeast support this and suggest that two to three CENP-B homologues are required to establish a functional centromere (Baum \& Clarke 2000, Irelan et al. 2001). On the other hand, there are many independent lines of evidence to show that CENP-B is expendable for mammalian centromere formation (Earnshaw et al. 1989, Sunkel \& Coelho 1995, Goldberg et al. 1996, Choo 1998). While gene knockout experiments in mice have indicated that Cenpb is nonessential for mitosis and meiosis (Hudson et al. 1998, Kapoor et al. 1998, Perez-Castro et al. 1998, TomascikCheeseman et al. 2002), it has been shown to be crucial for proper uterine development and function (Fowler et al. 2000).

Cenpb-null mice generated from early-generation heterozygous intercrosses on three different genetic backgrounds, known as R1, W9.5 and C57, displayed a marked reduction in uterine weight at 10 weeks old and demonstrated an age-dependent reproductive dysfunction that was more severe in the $\mathrm{C} 57 \mathrm{BL} / 6$ background. Breeding studies with 8-15-week-old C57 Cenpb-null female mice resulted in slow or difficult delivery of pups, whereas the R1 and W9.5 Cenpb-null females bred normally for the first three to four litters before developing pregnancy problems by the age of 9 months. Many overdue females 
sickened, and on autopsy dead intact or resorbing foeti and pyometra were found (Fowler et al. 2000).

When Cenpb-null early-generation mice were compared with age-matched wildtype female mice, no difference in ovarian tissues, progesterone and $\beta$-oestradiol levels or embryo number was detected. However, histological analysis of uterine tissue from 10-week-old C57 and 6-9-month-old R1 Cenpb-null females revealed abnormal luminal and glandular epithelium, fewer endometrial glands, and increased leucocyte infiltration, haemorrhage and infection. Furthermore, in situ hybridisation using a specific Cenpb-antisense probe detected high levels of Cenpb expression in the epithelial lining of the uterine lumen and endometrial glands of normal mice (Fowler et al. 2000). In this study we further explore the unexpected role of Cenpb in mouse uterine development and function. Our specific objective was to determine whether interbreeding Cenpb-null mice over successive generations would result in the exacerbation of the Cenpb-null phenotype, and, if so, what the underlying causes might be.

\section{Materials and Methods}

\section{Generation of Cenpb-null mice on R1, W9.5 and C57 backgrounds}

First-generation (G1) wildtype $\left(^{+/+}\right)$, null $\left(^{-/-}\right)$and heterozygous $\left({ }^{+-}\right)$mice from heterozygous intercrosses were maintained on two different mixed $129 \times \mathrm{C} 57 \mathrm{BL} / 6$ genetic backgrounds known as R1 and W9.5 (Fowler et al. 2000). Mice were bred as independent colonies, that is, $-/-x-/-,+1+\times+/+$ and $+/-x+/-$, for a further three generations (G2, G3 and G4). Due to known breeding difficulties with Cenpb-null females on a $\mathrm{C} 57 \mathrm{BL} / 6$ background (C57), $\mathrm{C} 57^{-/-}, \mathrm{C} 57^{+/-}$and $\mathrm{C} 57^{+/+}$ G1 mice were generated from heterozygous intercrosses (Fowler et al. 2000). The majority of mice used in this study were from cousin $\times$ cousin matings. All mice were genotyped by PCR (Fowler et al. 2000). Mice were housed in standard shoebox cages and allowed Barastoc feeder cubes and water ad libitum.

\section{Ethics of experimentation}

This study was conducted in accordance with Australian code of practice for the care and use of animals for scientific purposes and under approval of the Royal Children's Hospital Animal Ethics Committee (project numbers A388 and A450).

\section{Examination of mice for chronic infectious agents}

Serum samples from breeding colonies of mice were sent to the Murine Virus Monitoring Service, South Australia, for routine health testing every 6 months over the past 3 years. The sample size was statistically representative of mice in the colony and showed an absence of mouse hepatitis virus, rotavirus and parvovirus. In addition, the Department of Microbiology and Infectious Diseases, Royal Children's Hospital and Cerberus Sciences, South Australia, performed supplementary testing for known mouse uterine pathogens. Serum and uterine swabs were collected from 18-week-old G2 Cenpb-wildtype $(n=2)$, -null $(n=2)$ and -heterozygote $(n=4)$ virgin female mice and 10-11-week-old G3 Cenpb-wildtype $(n=2)$ and -null $(n=2)$ virgin female mice. Mice tested negative for minute virus of mice, mouse parvovirus, Mycoplasma pulmonis, Sendai virus, Chlamydia, Pasteurella pneumotropica and Salmonella enteritidis. No other bacterial pathogen of consequence was detected.

\section{Genomic scan of Cenpb-null mice on C57BL/6 background}

Tail DNAs from Cenpb-heterozygous mice on a C57BL/6 background $\left({\left.\mathrm{C} 57^{+-}\right)}^{+-}\right.$(Fowler et al. 2000) were sent to the Jackson Laboratory's Speed Congenic Service (Bar Harbor, ME, USA). Simple sequence length polymorphisms (SSLP) analysis using 108 markers that are polymorphic between C57 and 129 DNAs were used to determine the amount of residual 129 DNA surrounding the targeted Cenpb locus.

\section{Monitoring of mice for reproductive performance}

Breeding pairs were set up and females were examined for vaginal plugs, pregnancy and number of pups born by routine mouse husbandry procedures (Fowler et al. 2000).

\section{Organ weighing, histology and immunohistochemical analysis of endometrial gland cells}

Organ weights $(\mathrm{mg})$ were determined by weighing wet uteri and ovaries (Fowler et al. 2000). After weighing, mouse uteri were formalin-fixed, and a $2-3 \mathrm{~mm}$ piece of tissue was dissected from the mid-region of randomly selected left or right uterine horns and paraffin-embedded, and $5 \mu \mathrm{m}$ transverse sections were cut onto silanised slides and deparaffinised. Following antigen retrieval using DAKO Target Retrieval Solution, pH6 (S1699; DAKO, Carpinteria, CA, USA), in a water bath for $20 \mathrm{~min}$ at $95-99^{\circ} \mathrm{C}$, the slides were cooled for $20 \mathrm{~min}$ and equilibrated in Trisbuffered saline with Tween 20. After endogenous peroxidase activity was quenched using peroxidase blocking reagent (DAKO S2001) for $5 \mathrm{~min}$, polyclonal anti-progesterone receptor antibody (DAKO A0098), monoclonal anti-oestrogen receptor antibody (DAKO M7047) and antipan cytokeratin antibody (DAKO M3515) (Moll et al. 1982) were used at room temperature at dilutions of $1 / 50$, $1 / 50$ and $1 / 200$ respectively.

Monoclonal antibodies were stained according to manufacturer directions using the DAKO Animal Research Kit (K3954), which uses a modified avidin-biotin/peroxidase technique. Polyclonal antibody staining was carried out using the DAKO EnVision + /HRP (K4003), which uses an enzyme-labelled polymer technique. Immunolabelled 
cells were visualised with 3,3'-diaminobenzidine (K3468, DAKO) for $5 \mathrm{~min}$ and counterstained with Mayer's haematoxylin. All staining was performed using a DAKO Autostainer.

\section{Assessment of endometrial gland density}

To assess the number of glands in the uterine endometrial layer 2, haematoxylin and eosin-stained full-face transverse $5 \mu \mathrm{m}$ sections from the mid-region of randomly selected left or right uterine horns were examined microscopically. All visible glands were counted regardless of size, and the average was recorded for each section.

\section{Photomicrographs}

Images of stained sections were captured using an Olympus BX50 microscope equipped with a $10 \times$ eyepiece and $40 \times$ objective, and a CCD camera linked to an IBM computer with a $\mathrm{TCl}$-pro program. Digital images were assembled with PhotoShop, Version 6.0.

\section{Statistical analyses}

Values are presented as average \pm S.D. $P$ values were calculated using Student's $t$-test. $P$ values of less than 0.05 were regarded as significant.

\section{Ovarian transplantation studies}

Mice were anaesthetised with Avertin (tribromoethanol and amyl alcohol) (Hogan et al. 1994), and both ovaries were removed and replaced with one-half ovary per side, as described by Sztein et al. (1998), Mice were set up as breeding pairs with $\mathrm{C} 57 \mathrm{BL} / 6$ males 10 days after surgery and monitored daily.

\section{Results}

\section{Declining reproductive performance of G2, G3 and G4 Cenpb-null female mice}

The reproductive performance of Cenpb-wildtype $(+/+)$, -heterozygote $(+/-)$ and -null $(-/-)$ breeding pairs were observed over four generations of successive matings of genotype-specific intercrosses on R1 and W9.5 genetic backgrounds. $\mathrm{R} 1^{-/-}$mice produced significantly fewer pups at generations 2, 3 and $4(\mathrm{G} 2, \mathrm{G} 3$ and G4) than $\mathrm{R} 1^{+/+}$and $\mathrm{R} 1^{+/-}$breeding pairs (Table $1 \mathrm{~A}$ ) due to fewer litters being born (Table 1B). Comparison between $\mathrm{R} 1^{+/+}$ and $\mathrm{R} 1^{+/-}$breeding pairs showed no significant difference except for G3 intercrosses, where less pups and litters were produced by the $\mathrm{R} 1^{+/+}$pairs than the $\mathrm{R} 1^{+/-}$breeding pairs (Table $1 \mathrm{~A}$ and $\mathrm{B}$ ). A similar breeding record was observed for the $\mathrm{W} 9.5^{-1-}$ pairs when compared with W9. $5^{+/+}$matings (Table $2 \mathrm{~A}$ and $\mathrm{B}$ ). In addition, when reproductive performance was compared between G1 breeding pairs and G2, G3 and G4 breeding pairs, a general trend towards deteriorating reproductive outcome through successive generations in terms of numbers of pups and litters was observed, with the difference being particularly significant when G1 and G4 $\mathrm{W} 9.5^{-1-}$ mice were compared $(P \leq 0.005)$.

To determine whether the reduction in breeding performance of Cenpb-null mice was due to a problem in the males, females or both sexes, male and female G4 mice from $\mathrm{R} 1^{+/+}$and $\mathrm{R} 1^{-/-}$breeding pairs were mated to random-bred Swiss mice for 15 months. When compared with $\mathrm{R} 1^{+/+} \mathrm{G} 4$ male mice, the $\mathrm{R} 1^{-/-} \mathrm{G} 4$ males averaged a like number of total pups $(P=0.959$; Fig. $1 \mathrm{~A})$, litters $(P=1.0$; Fig. $1 \mathrm{~B})$ and pups per litter $(P=0.890$; Fig. $1 \mathrm{C})$. However, the $\mathrm{R} 1^{-1-} \mathrm{G} 4$ females, when examined against the $R 1^{+/+}$G4 females, produced significantly fewer pups $(P<0.001$; Fig. $1 \mathrm{~A})$, litters $(P=0.005 ;$ Fig. $1 \mathrm{~B})$ and pups per litter $(P=0.038$; Fig. 1C).

\section{G4 Cenpb-null mice show a similar reduction in uterus weight compared with Cenpb-null G1 mice from original heterozygous crosses}

To further investigate the observed decrease in reproductive performance in $\mathrm{G} 4 \mathrm{R} 1^{-/-}$and $\mathrm{W} 9.5^{-/-}$females, reproductive tissues from 10-week-old G4 mice (day 0.5 vaginal plug (VP)) were examined. The tissues included uterus, ovary and total number of embryos flushed from oviducts. Although 10 -week-old $\mathrm{R} 1^{-1-}$ and $\mathrm{W} 9.5^{-/-} \mathrm{G} 4$

Table 1 Declining reproductive performance of R1 Cenpb-deficient mice compared to wildtype and heterozygote breeding pairs.

\begin{tabular}{|c|c|c|c|c|c|c|}
\hline \multirow[b]{2}{*}{ Generation number } & \multicolumn{3}{|c|}{ Average number \pm S.D. } & \multicolumn{3}{|c|}{$\boldsymbol{P}$} \\
\hline & $+1+x+1+$ & $+1-\times+1-$ & $-1-\times-1-$ & $+1+\mathrm{vs}+1-$ & $+1+$ vs $-1-$ & $+1-$ vs $-1-$ \\
\hline \multicolumn{7}{|c|}{ A. Average number of pups per breeding pair } \\
\hline 1 & $50.6 \pm 36.0(n=4)$ & $39.5 \pm 19.1(n=2)$ & $13.3 \pm 9.5(n=3)$ & 0.711 & 0.146 & 0.123 \\
\hline 2 & $62.6 \pm 13.0(n=7)$ & $36.0 \pm 18.4(n=3)$ & $7.0 \pm 4.7(n=6)$ & 0.115 & 0.001 & 0.002 \\
\hline 3 & $50.7 \pm 20.8(n=5)$ & $87.3 \pm 12.5(n=3)$ & $6.0 \pm 6.5(n=6)$ & 0.025 & 0.001 & $<0.001$ \\
\hline 4 & $73.7 \pm 19.2(n=3)$ & $68.5 \pm 29.2(n=4)$ & $3.0 \pm 3.5(n=5)$ & 0.752 & $<0.001$ & 0.001 \\
\hline \multicolumn{7}{|c|}{ B. Average number of litters per breeding pair } \\
\hline 1 & $6.8 \pm 4.3(n=4)$ & $6.0 \pm 2.8(n=2)$ & $3.7 \pm 1.2(n=3)$ & 0.840 & 0.294 & 0.268 \\
\hline 2 & $9.1 \pm 1.2(n=7)$ & $5.5 \pm 3.5(n=3)$ & $1.7 \pm 1.0(n=6)$ & 0.283 & $<0.001$ & 0.035 \\
\hline 3 & $6.2 \pm 2.7(n=5)$ & $11.3 \pm 1.5(n=3)$ & $1.2 \pm 1.0(n=6)$ & 0.025 & 0.017 & $<0.001$ \\
\hline 4 & $9.3 \pm 2.1(n=3)$ & $10.0 \pm 3.5(n=4)$ & $0.8 \pm 0.8(n=5)$ & 0.983 & $<0.001$ & $<0.001$ \\
\hline
\end{tabular}

Mice were bred for approximately 12 months. $n=$ number of breeding pairs in study. 
Table 2 Reduced reproductive performance of $\mathrm{W} 9.5^{-/-}$mice compared to wildtype breeding pairs.

\begin{tabular}{lrrr}
\hline & \multicolumn{3}{c}{ Average number \pm s.D. } \\
\cline { 2 - 3 } Generation number & $+/+\times+/+$ & $-/-\times-/-$ & \multirow{2}{*}{$\boldsymbol{P}(+/+\mathrm{vs}-/-)$} \\
\hline A. Average number of pups per breeding pair & $33.0 \pm 7.2(n=3)$ & $10.0 \pm 1.7(n=3)$ & 0.006 \\
1 & $52.3 \pm 13.6(n=3)$ & $6.3 \pm 2.5(n=4)$ & 0.001 \\
2 & $65.3 \pm 16.9(n=6)$ & $4.4 \pm 3.2(n=5)$ & $<0.001$ \\
3 & $59.5 \pm 14.5(n=6)$ & $2.2 \pm 1.9(n=5)$ & $<.001$ \\
4 & $6.3 \pm 3.5(n=3)$ & $2.3 \pm 0.6(n=3)$ & $<0.001$ \\
B. Average number of litters per breeding pair & $9.0 \pm 1.0(n=3)$ & $1.5 \pm 1.0(n=4)$ & $<0.001$ \\
1 & $7.7 \pm 1.6(n=6)$ & $1.4 \pm 0.6(n=5)$ & $<0.001$ \\
2 & $9.2 \pm 1.8(n=6)$ & $0.8 \pm 0.5(n=5)$ & \\
3 & &
\end{tabular}

Mice were bred for approximately 12 months.
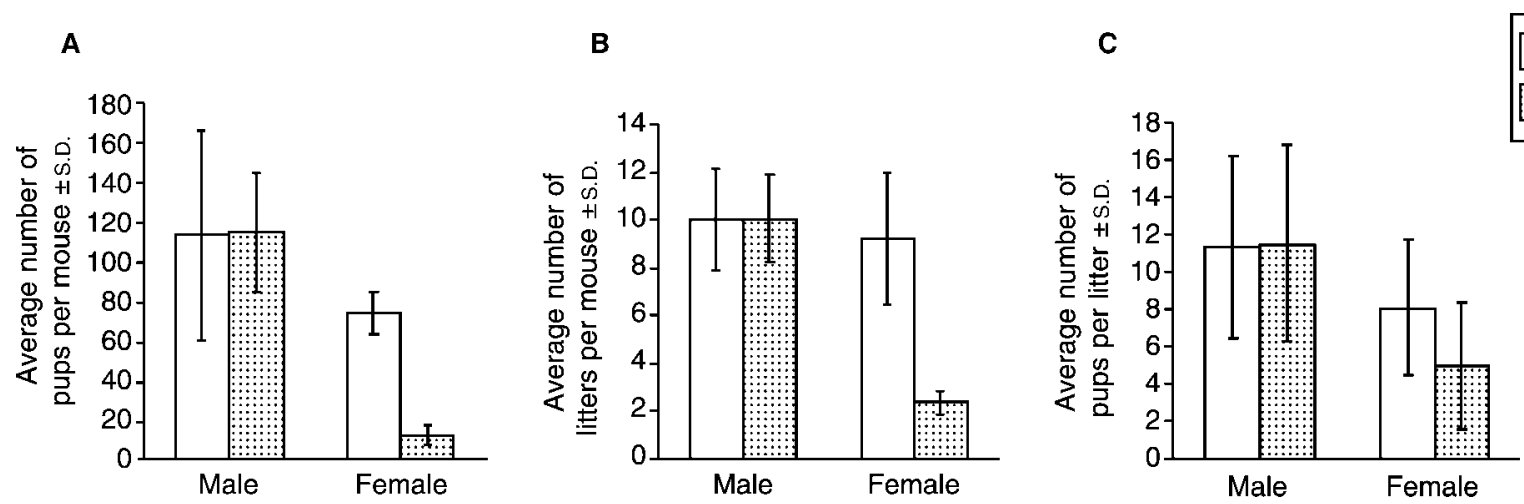

Figure 1 Reproductive ability of $6-10$-week-old G4 R $1^{+/+}$male $(n=4), \mathrm{R} 1^{-/-}$male $(n=5), \mathrm{G} 4 \mathrm{R} 1^{+/+}$female $(n=6), \mathrm{R} 1^{-/-}$female $(n=3)$ mice when mated to random-bred Swiss mice for up to 15 months. (A) Average number of total pups generated per mouse \pm S.D. (B) Average number of litters born per mouse \pm S.D. (C) Average number of pups per litter \pm S.D. Error bars represent S.D.

uteri were $59.0 \%$ and $37.0 \%$ smaller than $\mathrm{R} 1^{+/+}$and W9.5 $5^{+/+}$G4 uteri respectively (Table $3 \mathrm{~A}$ ), they were not smaller than 10-week-old $\mathrm{R} 1^{-1-}$ and $\mathrm{W} 9.5^{-/-} \mathrm{G} 1$ uteri from the original heterozygous crosses $\left(\mathrm{R} 1^{-1-} \mathrm{G} 1\right.$ : $79.7 \pm 27.8 \mathrm{mg}(n=7)$ vs $\mathrm{R} 1^{-1-}$ G $4: 55.9 \mathrm{mg}(n=1)$, $P=\mathrm{ND} ; \mathrm{W} .5^{-/-} \mathrm{G} 1: 82.5 \pm 19.0 \mathrm{mg}(n=5)$ vs $\mathrm{W} 9.5^{-1-}$ G4: 70.8 $17.2(n=4), P=0.376)$ (Fowler et al. 2000), suggesting that breeding through successive generations did not have an effect on the size of the uterus in the null mice.

\section{Reduced number of endometrial glands in G4 Cenpb- null mice}

Routine haematoxylin and eosin examination of full-face transverse sections of uterus from 10 -week-old W9.5 $5^{-1-}$ $(n=4)$ and $\mathrm{R}^{-1-}$ G4 mice $(n=1$; day $0.5 \mathrm{VP})$ from Cenpb-null intercrosses demonstrated no gross abnormality in the uterine epithelium but a significant decrease in the number of endometrial glands when compared with $\mathrm{W} 9.5^{+/+}(n=5)$ and $\mathrm{R} 1^{+/+}$G4 mice $(n=6)$ from wildtype intercrosses (Fig. 2A and B; Table $4 \mathrm{~A}$ and C).

Table 3 Uterus, ovary weights and number of embryos of 10-week-old homozygous G4 mice (day 0.5 VP) from Cenpb-wildtype or-null intercrosses.

\begin{tabular}{|c|c|c|c|c|}
\hline \multirow[b]{2}{*}{ Genetic Background } & \multicolumn{2}{|c|}{ Average weight \pm S.D. $(\mathrm{mg})$} & \multirow[b]{2}{*}{ Percent reduction } & \multirow[b]{2}{*}{$\boldsymbol{P}(+/+$ vs $-/-)$} \\
\hline & $+/+$ & $-1-$ & & \\
\hline \multicolumn{5}{|l|}{ A. Uterus } \\
\hline R1 & $137.5 \pm 64.1(n=6)$ & $55.9(n=1)$ & $59.0 \%$ & ND \\
\hline W9.5 & $112.6 \pm 13.3(n=5)$ & $70.8 \pm 17.2(n=4)$ & $37.0 \%$ & 0.006 \\
\hline \multicolumn{5}{|l|}{ B. Ovary } \\
\hline R1 & $14.1 \pm 4.3(n=6)$ & $8.0(n=1)$ & $43.0 \%$ & ND \\
\hline W9.5 & $12.4 \pm 2.2(n=5)$ & $12.2 \pm 1.9(n=4)$ & $2.0 \%$ & 0.870 \\
\hline \multicolumn{5}{|l|}{ C. Number of embryos } \\
\hline R1 & $9.7 \pm 1.1(n=6)$ & $8.0(n=1)$ & $18.0 \%$ & ND \\
\hline W9.5 & $9.0 \pm 1.9(n=5)$ & $7.3 \pm 2.6(n=4)$ & $19.0 \%$ & 0.280 \\
\hline
\end{tabular}

ND, not determined. 

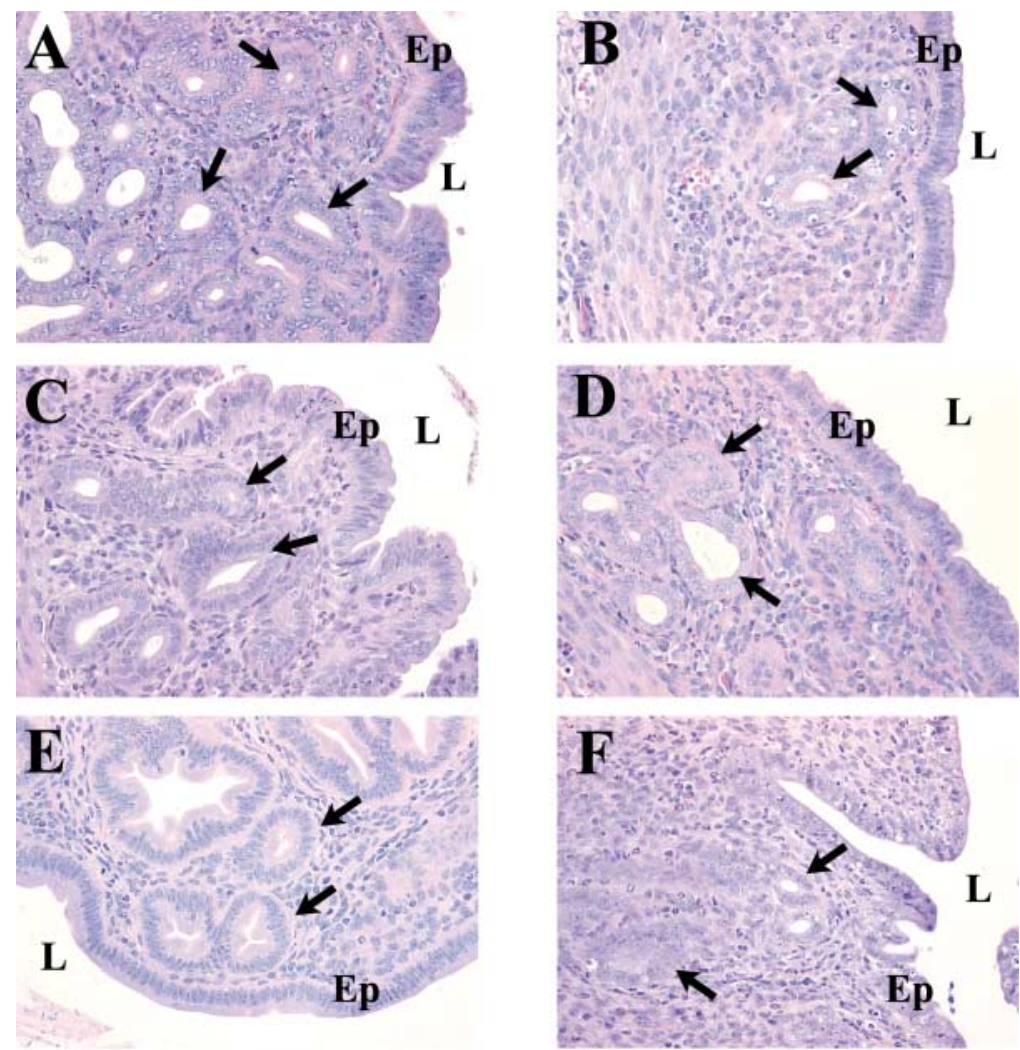

Figure 2 Haematoxylin and eosin analysis of uterus sections of wildtype and knockout 10- and 24-week-old G4 mice (day 0.5 VP) from homozygous and heterozygous breeding programmes. (A) W9.5 $5^{+/+} 10$-week-old uterus from homozygous breeding showing normal luminal epithelium and endometrial glands. (B) W9.5 $5^{-1-} 10$-week-old uterus from homozygous breeding showing normal luminal epithelium but a decrease in endometrial glands. (C) W9.5 $5^{+/+}$and (D) W9.5 10-week-old uterus from heterozygous breeding showing normal luminal epithelium and endometrial glands. (E) $\mathrm{R} 1^{+/+} 24$-week-old uterus from homozygous breeding showing normal luminal epithelium and an increase in endometrial glands. (F) $\mathrm{R} 1^{-/-}$24-week-old uterus
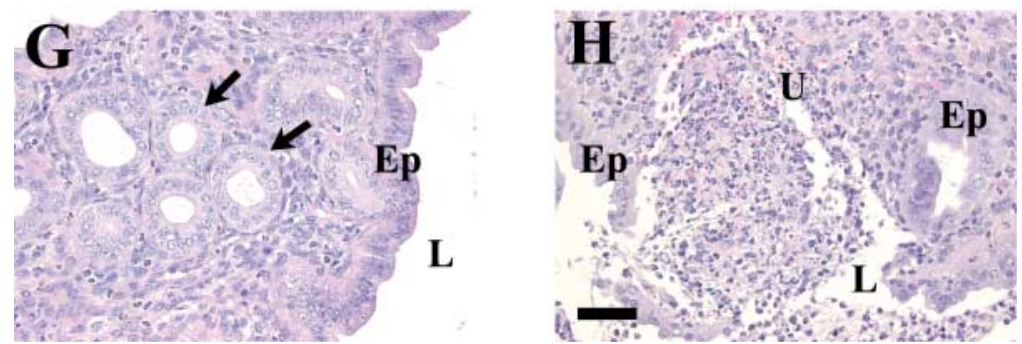
from homozygous breeding showing poor luminal epithelium and a decrease in endometrial glands. $(G)$ $\mathrm{R} 1^{+/+}$24-week-old uterus from heterozygous breeding showing normal luminal epithelium and endometrial glands. (H) $R 1^{-/-} 24$-week-old uterus from heterozygous breeding showing ulcerated luminal epithelium and a decrease in endometrial glands. Arrows mark endometrial glands; (Ep) marks epithelium; (L) marks lumen; $(U)$ marks ulcerated epithelium. Scale bar in panel $\mathrm{H}(50 \mu \mathrm{m})$ applies to all panels.

Table 4 Average number of endometrial glands in Cenpb-null and -wildtype G4 mice from homozygous and heterozygous crosses.

\begin{tabular}{|c|c|c|c|c|}
\hline \multirow[t]{2}{*}{ Parentage } & \multirow[t]{2}{*}{ Age (weeks) } & \multicolumn{2}{|c|}{$\begin{array}{c}\text { Average number of endometrial } \\
\text { glands } \pm \text { S.D. per } \\
\text { transverse section }\end{array}$} & \multirow[t]{2}{*}{$\boldsymbol{P}$} \\
\hline & & W9.5 ${ }^{+/+}$ & W9.5 ${ }^{-/-}$ & \\
\hline A. homozygous & 10 & $65.2 \pm 24.5(n=5)$ & $20.5 \pm 9.5(n=4)$ & 0.011 \\
\hline \multirow[t]{2}{*}{ B. heterozygous } & 10 & $28.7 \pm 11.9(n=3)$ & $16.7 \pm 9.7(n=3)$ & 0.248 \\
\hline & & $\mathbf{R} 1^{+/+}$ & $\mathbf{R} \mathbf{1}^{-/-}$ & \\
\hline C. homozygous & 10 & $24.0 \pm 8.6(n=6)$ & $6 \pm 0(n=1)$ & ND \\
\hline D. heterozygous & 10 & $39.0 \pm 21.8(n=4)$ & $21.0 \pm 8.5(n=4)$ & 0.175 \\
\hline E. homozygous & 24 & $108.5 \pm 36.1(n=6)$ & $8.0 \pm 0.0(n=2)$ & 0.010 \\
\hline F. homozygous & $32-36$ & $113.0 \pm 64.1(n=3)$ & $2.5 \pm 3.7(n=4)$ & 0.016 \\
\hline G. heterozygous & 24 & $76.3 \pm 25.9(n=4)$ & $7.6 \pm 8.7(n=5)$ & $<0.001$ \\
\hline H. heterozygous & $32-36$ & $82.8 \pm 44.7(n=4)$ & $8.8 \pm 5.9(n=5)$ & 0.007 \\
\hline
\end{tabular}

$\mathrm{ND}$, not determined. Uteri were collected at day 0.5 of vaginal plug except uteri from $32-36$-week-old mice were sampled from non-mated female mice. 
In contrast, 10-week-old W9.5 ${ }^{-/-}$G4 mice $(n=3)$ and $\mathrm{R} 1^{-/-} \mathrm{G} 4$ mice $(n=4)$ of the equivalent generation derived from heterozygous breeding pairs did not display a significant reduction in the number of endometrial glands when compared with littermate W9.5 ${ }^{+/+}(n=3)$ and $\mathrm{R} 1^{+/+}(n=4) \mathrm{G} 4$ mice respectively (Fig. $2 \mathrm{C}$ and D; Table 4B and D).

Next we examined haematoxylin and eosin sections from 24-week-old and 32-36-week-old G4 $\mathrm{R}^{-1-}$ and compared them to $\mathrm{G} 4 \mathrm{R}^{+/+}$age-matched controls from both homozygous and heterozygous breeding programmes. $\mathrm{R} 1^{-/-}$mice generated by either breeding strategy had significantly reduced numbers of endometrial glands (Table 4E-H). When 24- and 32-36-week-old G4 $\mathrm{R} 1^{-/-}$from heterozygous breeding (Table $4 \mathrm{G}$ and $\mathrm{H}$ ) were compared with 10-week-old G4 R1 $1^{-1-}$ (Table 4D), the number of endometrial glands had declined with ageing (10 vs 24 weeks, $P=0.053 ; 10$ vs 32 weeks, $P=0.037)$. On the other hand, the homozygous breeding regime resulted in $\mathrm{R}^{-1-} \mathrm{G} 4$ mice with a low number of endometrial glands at 10 weeks old that remained low with age (Table 4C, E and F). However, a reverse trend was observed in the wildtype R1 mice from the homozygous breeding strategy, in which the number of endometrial glands actually increased with age (Table 4C, $\mathrm{E}$ and $\mathrm{F} ; 10$ vs 24 weeks, $P<0.001 ; 10$ vs 32 weeks, $P=0.009$ ). Although the wildtype mice from the $\mathrm{R} 1^{+/+}$ heterozygous breeding programmes had increased their gland number with age, it was not significant (Table 4D, $\mathrm{G}$ and $\mathrm{H} ; 10$ vs 24 weeks, $P=0.070 ; 10$ vs 32 weeks, $P=0.129$ ).

\section{Abnormal luminal epithelium in uteri of 24-week-old $R 1^{-/-}$G4 mice}

Besides a reduction in endometrial gland number, uteri from 24-week-old $\mathrm{R}^{-1-} \mathrm{G} 4$ mice from heterozygous or homozygous breeding programmes $(n=7$ total) were observed to have ulcerated $(n=2)$ or disorganised $(n=1)$ luminal epithelium or oedema in the endometrium $(n=1$, Fig. $2 \mathrm{~F}$ and $\mathrm{H}$ ), whereas no obvious abnormality was noted in the uteri of control $\mathrm{R}^{+/+}$mice $(n=10$ total; Fig. 2E and G). Given the similarity of these observations to those seen in our previous study, we re-examined the haematoxylin and eosin slides of uteri of 24-week-old G1 mice from the original heterozygous crosses (Fowler et al. 2000). Counting of endometrial glands revealed a reduction in the average number of glands in $\mathrm{R} 1^{-1-} \mathrm{G} 1$ mice $(15.8 \pm 10.7 ; n=5)$ when compared with $\mathrm{R} 1^{+/+} \mathrm{G} 1$ mice $(50.1 \pm 35.1 ; n=7)$, but the difference was not statistically significant $(P=0.080)$.

\section{Greatly reduced number of endometrial glands in 3-, 4-, 6-, 8-, 10- and 24-week-old $\mathrm{C}^{-1-} \mathrm{G} 7^{-/}$mice}

The observed reduction in the number of endometrial glands of $\mathrm{R}^{-1-}$ and $\mathrm{W} 9.5^{-/-} \mathrm{G} 4$ mice and the more severe breeding problems of Cenpb-null and -wildtype mice on the C57BL/6 background (Fowler et al. 2000) prompted us to examine uterine sections of $\mathrm{C} 7^{-1-}$ and $\mathrm{C} 57^{+/+}$mice at $3,4,6,8,10$ and 24 weeks of age at G1. $\mathrm{C} 57^{-1-}$ females were found to have a significant reduction in gland number when compared with agematched ${\mathrm{C} 57^{++}}^{+/}$(Table 5A-F), suggesting that the endometrial glands failed to develop properly during the pre- and post-pubertal period on this genetic background.

\section{Birthing problems and reduced number of endometrial glands in 24-week-old $\mathrm{C}_{5} 7^{+/-}$G1 mice}

During routine maintenance of the $\mathrm{C}_{5} 7^{+/-}$breeding colony, it was observed that some of the $\mathrm{C} 57^{+/-}$breeding females developed birthing problems as they approached 24 weeks old. This was reminiscent of the phenotype formerly observed with 8-15-week-old $\mathrm{C}_{5} 7^{-1-}$ breeding females (Fowler et al. 2000). In the present study, 10 previously non-mated, 24 -week-old $\mathrm{C} 57^{+/-}$and $\mathrm{C} 57^{+/+}$ females were set up with fertile stud males. Of the $\mathrm{C} 57^{+/-}$ females, $70 \%$ developed birthing problems and 10\% developed pyometra, as compared with only one $\mathrm{C} 57^{+/+}$ female developing a birthing problem. Histological analysis of uteri of previously non-mated, 24-week-old mice (day $0.5 \mathrm{VP})$ revealed a significant reduction $(P<0.001)$ in endometrial gland number in $\mathrm{C} 57^{+/-}$mice $(45.2 \pm 16.7$; $n=7)$ compared with $\mathrm{C} 57^{+/+}$mice $(83.6 \pm 3.0 ; n=5)$. In contrast, 10 -week-old ${\mathrm{C} 57^{+/-}}^{+}$mice that breed normally had no decrease $(P=0.713)$ in their endometrial gland number $(22.3 \pm 2.4 ; n=4)$ when compared with $\mathrm{C} 57^{+/+}$ mice $(22.6 \pm 11.2 ; n=5)$.

Table 5 Average numbers of endometrial glands in $\mathrm{C} 57^{+/+}, \mathrm{C} 57^{+/-}$ and $\mathrm{C} 57^{-/-}$mouse uteri at different ages.

\begin{tabular}{|c|c|c|c|}
\hline Genotype & $\begin{array}{l}\text { Number } \\
\text { of mice }\end{array}$ & $\begin{array}{l}\text { Average number } \\
\text { of endometrial } \\
\text { glands } \pm \text { S.D. per } \\
\text { transverse section }\end{array}$ & $\boldsymbol{P}(+/+\mathrm{vs}-/-)$ \\
\hline \multicolumn{4}{|c|}{ A. 3-week-old } \\
\hline $\mathrm{C} 57^{+/+}$ & 7 & $5.6 \pm 1.6$ & \multirow[t]{2}{*}{0.001} \\
\hline $\mathrm{C} 57^{-1-}$ & 4 & $0.5 \pm 0.5$ & \\
\hline \multicolumn{4}{|c|}{ B. 4-week-old } \\
\hline $\mathrm{C} 57^{+/+}$ & 3 & $8.7 \pm 3.1$ & \multirow{2}{*}{0.051} \\
\hline $\mathrm{C} 57^{-1-}$ & 4 & $4.0 \pm 1.8$ & \\
\hline \multicolumn{4}{|c|}{ C. 6-week-old } \\
\hline $\mathrm{C} 57^{+/+}$ & 2 & $12.0 \pm 2.8$ & \multirow[t]{2}{*}{0.042} \\
\hline $\mathrm{C} 57^{-1-}$ & 3 & $2.7 \pm 3.1$ & \\
\hline \multicolumn{4}{|c|}{ D. 8-week-old } \\
\hline $\mathrm{C} 57^{+/+}$ & 4 & $22.8 \pm 5.4$ & \multirow[t]{2}{*}{0.006} \\
\hline $\mathrm{C} 57^{-1-}$ & 4 & $8.5 \pm 4.4$ & \\
\hline \multicolumn{4}{|c|}{ D. 10-week-old } \\
\hline $\mathrm{C} 57^{+/+}$ & 5 & $22.6 \pm 11.2$ & \multirow[t]{2}{*}{0.039} \\
\hline $\mathrm{C} 57^{-1-}$ & 4 & $7.8 \pm 3.3$ & \\
\hline \multicolumn{4}{|c|}{ F. 24 week-old } \\
\hline $\mathrm{C} 57^{+/+}$ & 5 & $83.6 \pm 3.0$ & \multirow[t]{2}{*}{$<0.001$} \\
\hline $\mathrm{C} 57^{-1-}$ & 2 & $5.0 \pm 0$ & \\
\hline
\end{tabular}

Female mice from heterozygote crosses on a C57BL/6 background were used. Uteri were collected at day 0.5 of vaginal plug except for prepubertal uteri from 3- and 4- week-old non-mated C57 females. 


\section{Immunohistochemical analysis of endometrial gland cells}

It was noted when counting the haematoxylin and eosinstained glands in the uterine endometrium of Cenpb-null mice that some glands had markedly reduced lumens as compared with the glands of wildtype mice (Fig. 3A and B). To ensure that all glands were being scored on the haematoxylin and eosin sections, a number of slides were stained with anti-pan cytokeratin antibody, which marks epithelial cells (Moll et al. 1982) (Fig. 3C and D). The counting results were comparable, indicating that the assessment on haematoxylin and eosin sections was accurate. To examine whether the glandular epithelium layer of $\mathrm{R} 1^{-/-} \mathrm{G} 4$ mice had retained oestrogen and progesterone receptors, sections of uterus from 32-36-week-old, non-mated mice were stained with anti-oestrogen receptor and anti-progesterone receptor antibodies. Positive-staining nuclei at apparently comparable density were present in the endometrial glands and stroma of $\mathrm{R} 1^{-/-}$and $\mathrm{R} 1^{+/+}$ G4 mice, suggesting that functional oestrogen (Fig. 3E and $\mathrm{F}$ ) and progesterone (Fig. $3 \mathrm{G}$ and $\mathrm{H}$ ) receptors were present in the $\mathrm{R} 1^{-/-}$mice.

\section{Normal ovarian function in G4 Cenpb-null mice}

To determine whether the ovaries of Cenpb-null mice had deteriorated following interbreeding for several generations, ovaries from Cenpb-null and -wildtype G4 mice (day $0.5 \mathrm{VP}$ ) were weighed and the number of embryos was assessed following mating to wildtype stud males. No reduction was observed in ovary weight or number of embryos of $\mathrm{R} 1^{-/-}$and $\mathrm{W} 9.5^{-/-}$G4 mice when compared with $\mathrm{R} 1^{+/+}$and $\mathrm{W} 9.5^{+/+}$G4 mice respectively, suggesting that ovarian function in terms of egg production was unaffected by the gene knockout mutation (Table 3B and C).

\section{Ovarian transplantation fails to rescue the poor breeding performance of Cenpb-null mice}

Further evidence that the ovary was not responsible for the poor breeding performance of young adult Cenpb-null mice was provided by the failure of ovarian transplantation to rescue the phenotype. $\mathrm{R} 1^{+/+}$and $\mathrm{R} 1^{-/-} \mathrm{G} 4$ mice 7-9 weeks old were transplanted with ovaries from 4-week-old $\mathrm{R} 1^{+/+}$G4 mice, as described by Sztein et al. (1998) The wildtype ovaries failed to give rise to normal numbers of litters and pups in the $\mathrm{R} 1^{-1-}$ females. The $\mathrm{R} 1^{-1-}$ females $(n=5)$ averaged just one litter of $2.0 \pm 1.6$ pups per litter, whereas transplanted $\mathrm{R} 1^{+/+}$mice $(n=6)$ were able to generate, on average, 5.8 \pm 1.0 litters with $4.8 \pm 2.3$ pups per litter. When the transplanted mice were 9 months old, they were culled, and the number of endometrial glands per transverse uterine section was assessed. The $\mathrm{R} 1^{+/+}$mice had $36.0 \pm 19.3$ glands per transverse section, whereas the $\mathrm{R} 1^{-/}$mice had $6.0 \pm 5.6$ glands $(P=0.043)$. Furthermore, when 5 -week-old $\mathrm{R} 1^{+/+}$ G4 mice $(n=2)$ were transplanted with ovaries from 32-week-old $\mathrm{R} 1^{-/-}$G4 mice, the mice were able to produce an average of $5.5 \pm 0.7$ litters with $4.4 \pm 2.3$ pups per litter.

In addition, four virgin, 24-week-old $\mathrm{C}_{5} 7^{+/-}$G1 females underwent ovarian transplantation with 4-weekold C57BL/6 ovaries. One female failed to become pregnant and two females developed birthing problems with their first litter similar to their non-transplanted counterparts.

\section{Genome scan analysis of $\mathrm{C}_{5} 7^{+/-}$mice}

DNA microsatellite markers that detect polymorphisms between 129 and C57BL/6 DNAs were used to determine the amount of remaining 129-derived DNA in Cenpb-null mice on C57BL/6 background. Genome scan analysis revealed a residual 129 region encompassing approximately $41 \mathrm{cM}$ around the targeted Cenpb locus (73 cM position) on chromosome 2 (mouse genome database, MGD). The closest C57 markers were located at the 43 and $84 \mathrm{cM}$ positions, 129 markers being present at 52 and $69 \mathrm{cM}$.

\section{Discussion}

The lack of reproductive performance in 10-week-old $\mathrm{R} 1^{-/-}$and $\mathrm{W} 9.5^{-1-}$ G4 mice appears to be mainly due to a reduction in endometrial gland density that was exacerbated by generations of Cenpb-null breeding. Although 10-week-old $\mathrm{R} 1^{-1-}$ and $\mathrm{W} 9.5^{-1-}$ G4 mice displayed a smaller uterus than wildtype G4 mice, they were no different in size from their Cenpb-null G1 counterparts derived from heterozygote intercrosses. Likewise, histological examination of the luminal and glandular epithelium, endometrium and myometrium of 10 -week-old R $1^{-/-}$and W9.5 $5^{-1-}$ G4 mice revealed no gross abnormality. On the other hand, the luminal epithelia of $43 \%$ of 24 -week-old R1 ${ }^{-/-}$G4 mice $(n=7)$ displayed ulcerated or disorganised epithelia similar to $60 \%$ of 24 -week-old $R 1^{-1-}$ G1 mice observed in our previous study $(n=5)$ (Fowler et al. 2000).

The significant reduction in the number of endometrial glands of 10 -week-old $\mathrm{R} 1^{-1-}$ and $\mathrm{W} 9.5^{-1-}$ G4 mice (Table 4A and $\mathrm{C}$ ) is intriguing. It would appear that Cenpb-null G4 females carried and reared by a Cenpbheterozygote R1 or W9.5 dam surrounded by heterozygous and wildtype littermates were not quite as susceptible to significant decreases in endometrial gland number at 10 weeks old (Table 4B and D). However, by 24 weeks of age, any possible parental R1 or W9.5 heterozygote effect had dissipated, as Cenpb-null G4 mice from both homozygous and heterozygous breeding pairs were noted to have significantly lower numbers of endometrial glands (Table 4E and G).

Further support for endometrial gland development being influenced pre- and postpubertally can be gleaned from the Cenpb-null mice on a C57BL/6 background. On this background the uterine phenotype of Cenpb-null 

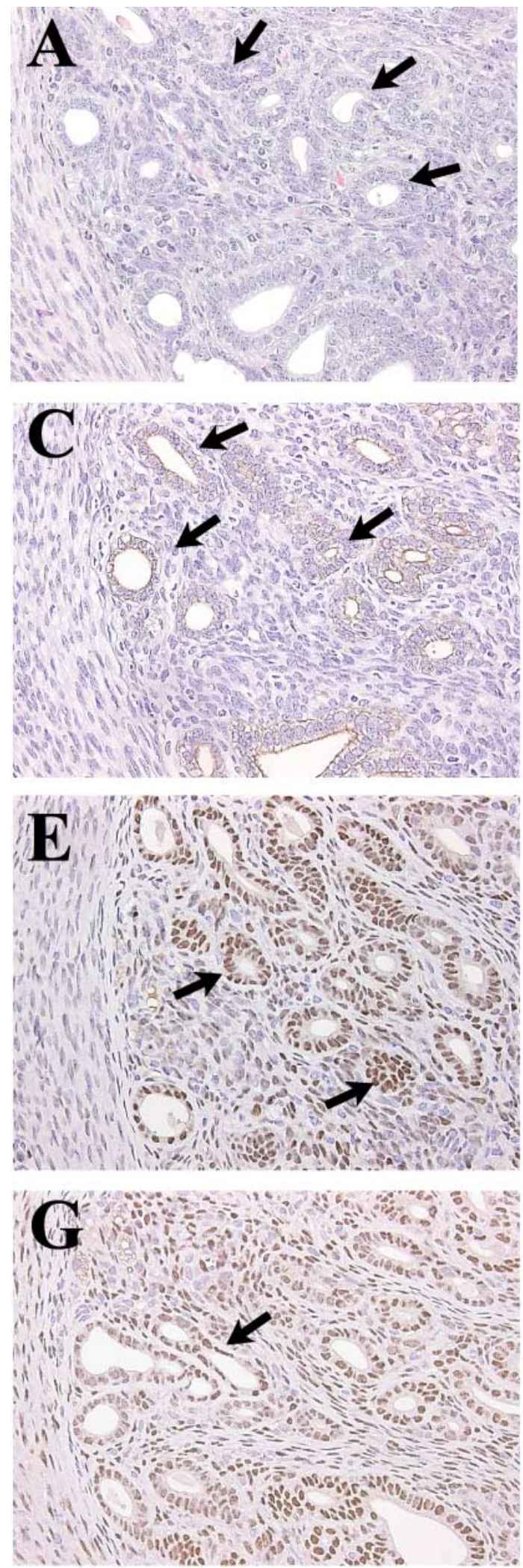
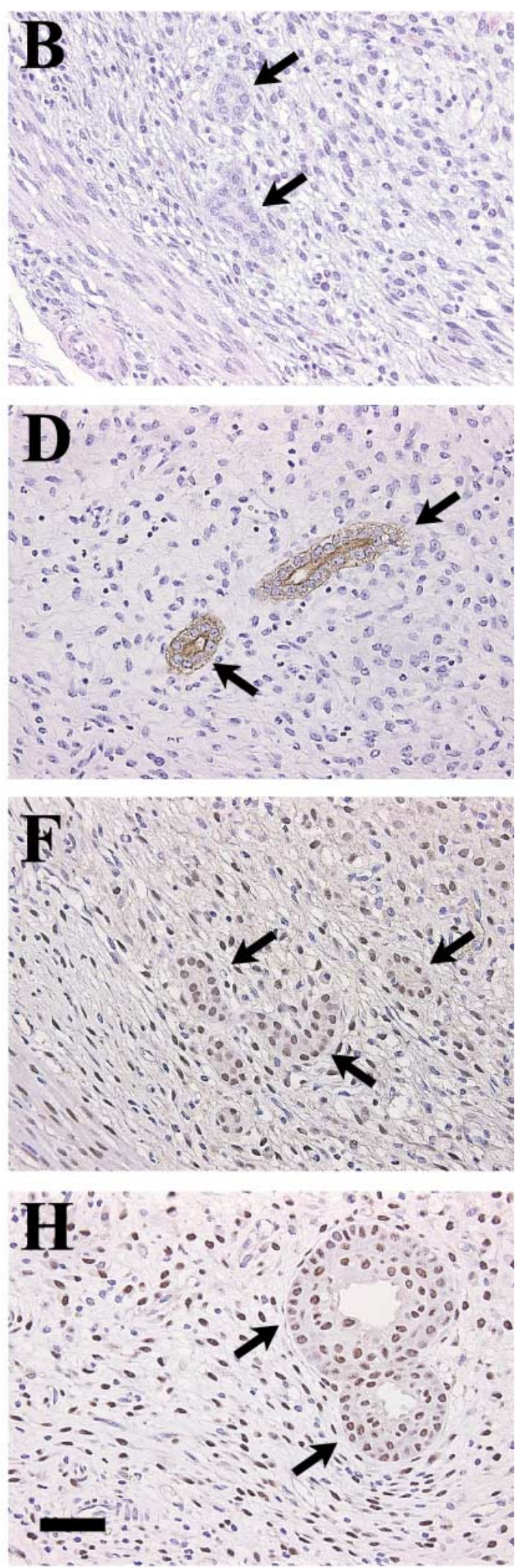
mice has been reported as being more dramatic (Fowler et al. 2000). Disorganisation of luminal and glandular epithelium was observed in the uteri of 10-week-old $\mathrm{C} 57^{-/-}$ G1 mice $(n=4), 50 \%$ displaying ulcerated luminal epithelia when compared with $\mathrm{C} 57^{+/+} \mathrm{G} 1$ mice $(n=3)$ that exhibited normal epithelia. Besides abnormal uterine epithelium, a reduction in the number of endometrial glands in 10-week-old $\mathrm{C}_{5} 7^{-1-}$ G1 mice was previously noted, but not quantified (Fowler et al. 2000). In the current study, 3-week-old $\mathrm{C}_{5} 7^{-1-}$ G1 mice carried by a $\mathrm{C} 57^{+/-}$dam were found to have a $90 \%$ reduction in their endometrial gland number (Table $5 \mathrm{~A}$ ) that remained low up until at least 24 weeks old (Table 5B-F).

As well as abnormal uterine epithelium, our previous studies have shown that the majority of 8-15-week-old $\mathrm{C} 57^{-1-} \mathrm{G} 1$ breeding females developed birthing problems (Fowler et al. 2000). In the present study pregnancy problems and impaired gland development were observed in 24-week-old heterozygote C57 G1 females. Histologically, 24-week-old $\mathrm{C} 57^{+/-}$displayed a similar profile of endometrial gland scarcity.

Genome scan analysis of $\mathrm{C}_{5} 7^{+/-}$DNA revealed a $41 \mathrm{cM}$ region of residual embryonic stem cell-derived 129 DNA. Previously, Kapoor et al. (1998) had proposed that the phenotypic differences seen in their mice and ours might be due to neighbouring gene effect. Of interest are genes known as progestogen-dependent endometrial protein (Paep) (Chan et al. 1994) and cyclin-dependent kinase-1 (Cdc25b) (Lock et al. 1996) that have been previously assigned to the $73 \mathrm{cM}$ position on mouse chromosome 2 in the region of Cenpb (Jackson Laboratory MGD). With respect to Paep, neither the NCBI nor Celera mouse databases have located Paep in the mouse genome, although PAEP has been confirmed in the human genome (GDB: 6276819). In regard to Cdc25b, knockout mouse studies have revealed a female sterility problem that is specifically due to $\mathrm{Cdc} 25 \mathrm{~b}^{-1-}$ oocytes being arrested during meiosis, rather than a uterine problem (Lincoln et al. 2002). Furthermore, our previous work describing the generation and normal phenotype of a targeted control mouse that carried the internal ribosome entry site (IRES)neomycin selectable marker element in the Cenpb gene, but not the translational frameshift mutation, suggests that the observed phenotype in Cenpb-null mice is due to Cenpb-gene disruption rather than a nearby gene effect induced by the targeting construct (Fowler et al. 2000).

The lack of endometrial glands in the Cenpb-null mice resembles the phenotype observed in sheep that were treated neonatally with synthetic progesterone known as norgestomet (Gray et al. 2001). Keeping the ovine uterus in a progesterone-rich postnatal environment suppressed epithelial oestrogen receptor- $\alpha$ protein expression and altered the expression of normal paracrine cues for the development and proliferation of endometrial glands from the luminal epithelium (Gray et al. 2000). This resulted in a permanent ablation of endometrial glands and subsequent implantation failure and loss of reproductive fitness in treated ewes transplanted with normal blastocysts. Unlike the Gray studies, we have found no evidence of abnormal hormone levels (Fowler et al. 2000) or loss of oestrogen receptor expression contributing to the lack of endometrial glands observed in Cenpb-null mice. However, future studies on the expression levels of other growth factors and/or receptors involved in endometrial gland formation or uterine receptivity (Gray et al. 2000, 2001, Cheng et al. 2001) may help shed light on the uterine phenotype of Cenpb-null mice.

Interestingly, some aspects of the phenotype of G1 Cenpb-null mice (Hudson et al. 1998, Fowler et al. 2000) are reminiscent of telomerse-deficient mice $\left(\mathrm{mTR}^{-1-}\right)$ following intermating over a number of generations (Lee et al. 1998, Herrera et al. 1999b). Generation $4 \mathrm{mTR}^{-/-}$ mice on a mixed C57BL6/129Sv background were found to have significantly smaller litters than $\mathrm{G} 1 \mathrm{mTR}^{-/-}$mice, whereas generation 6 intercrosses exhibited infertility due to a number of factors, including a possible compromise in uterine structure and function (Lee et al. 1998, Herrera et al. 1999a). The worsening phenotype of the $\mathrm{mTR}^{-1-}$ mice was linked to a reduction in telomere-length and chromosomal abnormalities. This phenotype was exacerbated when $\mathrm{mTR}^{-/-}$mice were generated on a $\mathrm{C} 57 \mathrm{BL} / 6$ background with mice being fertile only to the third generation (Lee et al. 1998, Herrera et al. 1999b). These observations suggest that Cenpb may be essential for short- and long-term maintenance of uterine integrity over a number of generations.

By virtue of its constitutive centromere-binding property, any attempt at deciphering a role of Cenpb has to date been directed at some aspects of chromosome segregation behaviour. Furthermore, if such a role is functionally important, then any perturbation of the protein function would be expected to result in a missegregation outcome throughout all actively dividing tissues in the mice, as gene knockouts of other key centromere-binding proteins have shown (Kalitsis et al. 1998, 2000, Dobles et al. 2000, Uren et al. 2000, Babu et al. 2003). It is therefore surprising that the phenotype seen in our Cenpb-null mice appears to be confined to the uterine

Figure 3 Haematoxylin and eosin and immunohistochemical analysis of endometrial glands of $\mathrm{R} 1^{+/+}$and $\mathrm{R} 1^{-/-} 32-36$-week-old non-mated mice. (A) Haematoxylin and eosin stained $\mathrm{R} 1^{+/+}$endometrium showing normal glands. (B) Haematoxylin and eosin stained $\mathrm{R} 1^{-1-}$ endometrium showing fewer glands. $(\mathrm{C}$ and $\mathrm{D})$ Anti-pan cytokeratin antibody-stained $\mathrm{R} 1^{+/+}$and $\mathrm{R} 1^{-/-}$endometria respectively, showing brown positive staining in the cytoplasm of $\mathrm{R} 1^{+/+}$and $\mathrm{R} 1^{-/-}$endometrial glandular epithelium. (E and $\mathrm{F}$ ) Anti-oestrogen receptor antibody-stained $\mathrm{R} 1^{+/+}$and $\mathrm{R} 1^{-/-}$endometria respectively, showing brown positive staining in the nuclei of $\mathrm{R} 1^{+/+}$and $\mathrm{R} 1^{-/-}$endometrial glandular epithelium and stroma. $(\mathrm{G}$ and $\mathrm{H})$ Anti-progesterone receptor antibody-stained $\mathrm{R} 1^{+/+}$and $\mathrm{R} 1^{-/-}$endometrium, showing brown positive staining in the nuclei of $\mathrm{R} 1^{+/+}$ and $\mathrm{R} 1^{-/-}$endometrial glandular epithelium and stroma. Arrows mark endometrial glands. Scale bar in panel $\mathrm{H}(50 \mu \mathrm{m})$ applies to all panels. 
tissues. While it is true that uterine tissue has a high expression level of Cenpb mRNA in mouse (Fowler et al. 2000), other tissues with similar Cenpb expression, such as mouse testes and intestinal epithelium ( $\mathrm{K}$ J Fowler, unpublished observations), are not affected functionally by the null mutation, suggesting that high mRNA alone is insufficient to explain the observed uterine phenotype.

Studies in the fission yeast Schizosaccharomyces pombe have identified three CENP-B homologues Adp1, Cbh1 and Cbh2 (Baum \& Clarke 2000, Irelan et al. 2001). Knockout experiments on these genes have shown that the ablation of one alone causes only a mild phenotype, whereas deletion of two of these genes, Adp1 and Cbh1 or Adp1 and Cbh2, results in severe defects in chromosomal segregation and cell growth (Baum \& Clarke 2000, Irelan et al. 2001). These studies indicate the functional redundancy of the Adp1, Cbh1 and Cbh2 proteins. Although at present no CENP-B functional homologue(s) have been identified in mammals, including mice, it is conceivable that such homologue(s) exist, and this would explain the general non-essential nature of Cenpb. It is further possible that any such redundant protein(s) may not be able to replace fully the functions of Cenpb, and that the uterine tissue is particularly sensitive to such functional discrepancy. Our observation that the uterine phenotype becomes progressively more severe with increase in both age of the mice and generation time appears consistent with the speculation that the inadequacies of the putative CENP-B homologues could be exacerbated through increasing numbers of both mitotic and meiotic passages.

How does Cenpb exert the observed uterine effect? Although Cenpb is related to transposase by sequence homology, it has lost its transposase activity (Kipling \& Warburton 1997), and, as such, any role it might have is unlikely to be directly linked to transposase. As indicated both in the present and our earlier study (Fowler et al. 2000), the contrasting severity of the uterine phenotype in different mouse strains is another example where the roles of modifier genes are strongly implicated in phenotypic presentation (Banbury Conference Consortium 1997, Threadgill et al. 1995, Herrera et al. 1999a). However, what these modifier genes in Cenpb-null mice are remains unknown. A potentially useful future effort to resolve what role Cenpb might play in uterine morphogenesis and, more generally, in mitotic and meiotic cell divisions, may be in attempts to identify its functional homologue(s) in mammals, as, if these exist, they could provide the missing pieces to the puzzle.

In summary, the observed decrease in endometrial glands in the Cenpb-null mouse leads to a lack of reproductive capability, indicating that a certain number of endometrial glands are required to establish successful pregnancies. Of note is the fact that this decrease in endometrial gland development is caused by the targeted knockout of a gene, the function of which is known to be specific to the centromere. Furthermore, the decreasing endometrial phenotype is exacerbated through successive generations of breeding. The underlying mechanisms responsible for these observations are at present unclear. These mice offer a model for studying these mechanisms as well as possible genetic and physiological requirements for endometrial glands during pregnancy.

\section{Acknowledgements}

We thank S. Gazeas, N. Kerr and C. Turner for care of mice; A. Sylvain, J. Broughton and B. McComb for extraction of mouse tail DNA; C. Pearce and Y. Mueller of $\mathrm{RCH}$ Department of Microbiology and Infectious Diseases and B. Stevenson, formerly of Murine Virus Monitoring Service, now at Cerberus Sciences, for health testing of mice; C.W. Chow, M. Pauchnik, T. Bouras and staff of RCH Anatomical Pathology Laboratory for histology; and D. Walls of the Jackson Laboratory for SSLP analysis.

\section{References}

Babu JR, Jeganathan KB, Baker DJ, Wu X, Kang-Decker N \& van Deursen JM 2003 Rae1 is an essential mitotic checkpoint regulator that cooperates with Bub3 to prevent chromosome missegregation. Journal of Cell Biology $160341-353$.

Baum M \& Clarke L 2000 Fission yeast homologs of human CENP-B have redundant functions affecting cell growth and chromosome segregation. Molecular and Cellular Biology 20 2852-2864.

Bernat RL, Borisy GG, Rothfield NF \& Earnshaw WC 1990 Injection of anticentromere antibodies in interphase disrupts events required for chromosomal movement at mitosis. Journal of Cellular Biology 111 1519-1533.

Bernat RL, Delannoy MR, Rothfield NF \& Earnshaw WC 1991 Disruption of centromere assembly during interphase inhibits kinetochore morphogenesis and function in mitosis. Cell $\mathbf{6 6}$ 1229-1238.

Chan P, Simon-Chazottes D, Mattei MG, Guenrt JL \& Salier JP 1994 Comparative mapping of lipocalin genes in human and mouse: the four genes for complement C8 $\gamma$ chain, prostaglandin-D-synthase, oncogene-24P3 and progestagen-associated endometrial protein map to HSA9 and MMU2. Genomics 23 145-150.

Cheng JG, Chen JR, Hernandez L, Alvord WG \& Stewart CL 2001 Dual control of LIF expression and LIF receptor function regulate Stat 3 activation at the onset of uterine receptivity and embryo implantation. PNAS 98 8680-8685.

Choo KHA 1998 Turning on the centromere. Nature Genetics 18 $3-4$.

Cooke CA, Bernat RL \& Earnshaw WC 1990 CENP-B: a major human centromere protein located beneath the kinetochore. Journal of Cellular Biology 110 1475-1488.

Dobles M, Liberal V, Scott ML, Benezra R \& Sorger PK 2000 Chromosome missegregation and apoptosis in mice lacking the mitotic checkpoint protein Mad2. Cell 101 635-645.

Earnshaw WC, Sullivan KF, Machlin PS, Cooke CA, Kaiser DA, Pollard TD, Rothfield NF \& Cleveland DW 1987 Molecular cloning of CDNA for CENP-B, the major human centromere autoantigen. Journal of Cellular Biology 104 817-829.

Earnshaw WC, Ratrie H \& Stetten G 1989 Visualization of centromere proteins CENP-B and CENP-C on a stable dicentric chromosome in cytological spreads. Chromosoma 98 1-12.

Fowler KJ, Hudson DF, Salamonsen L, Edmondson S, Earle E, Sibson MC \& Choo KHA 2000 Uterine dysfunction and genetic modifiers in centromere protein B-deficient mice. Genome Research $\mathbf{1 0}$ $30-41$. 
Goldberg IG, Sawhney H, Pluta AF, Warburton PE \& Earnshaw WC 1996 Surprising deficiency of CENP-B binding sites in African green monkey alpha-satellite DNA: implications for CENP-B function at centromeres. Molecular and Cellular Biology 169 $5156-5168$

Gray CA, Taylor KM, Bazer FW, Bartol FF \& Spencer TE 2000 Mechanisms regulating norgestomet inhibition of endometrial gland morphogenesis in the neonatal ovine uterus. Molecular Reproduction and Development 57 67-78.

Gray CA, Taylor KM, Ramsey WS, Hill JR, Bazer FW, Bartol FF \& Spencer TE 2001 Endometrial glands are required for preimplantation conceptus elongation and survival. Biology of Reproduction 64 1608-1613.

Herrera E, Samper E \& Blasco MA 1999a Telomere shortening in $\mathrm{mTR}^{-1}$ - embryos is associated with failure to close the neural tube. EMBO Journal $181172-1181$.

Herrera E, Samper E, Martin-Caballero J, Flores JM, Lee H-W \& Blasco MA $1999 b$ Disease states associated with telomerase deficiency appear earlier in mice with short telomeres. EMBO Journal 11 2950-2960.

Hogan B, Beddington R, Constantini F \& Lacy E 1994 Manipulating the Mouse Embryo: A Laboratory Manual. Cold Spring Harbor, NY: Cold Spring Harbor Press.

Hudson DF, Fowler KJ, Earle E, Saffery R, Kalitsis P, Trowell H, Hill J, Wreford NG, deKretser DM, Cancilla MR, Howman E, Hii L, Cutts SM, Irvine DV \& Choo KHA 1998 Centromere protein $\mathrm{B}$ null mice are mitotically and meiotically normal but have lower body and testis weights. Journal of Cellular Biology $141309-319$.

Irelan JT, Gutkin GI \& Clarke L 2001 Functional redundancies, distinct localizations and interactions among three fission yeast homologs of centromere protein-B. Genetics 157 1191-1203.

Kalitsis P, Fowler KJ, Earle E, Hill J \& Choo KHA 1998 Targeted disruption of mouse centromere protein $\mathrm{C}$ leads to mitotic disarray and early embryo death. PNAS 95 1136-1141.

Kalitsis P, Earle E, Fowler KJ \& Choo KHA 2000 Bub3 gene disruption in mice reveals essential mitotic spindle checkpoint function during early embryogenesis. Genes and Development 14 2277-2282.

Kapoor M, Montes de Oca Luna R, Liu G, Lozano G, Cummings C, Mancini M, Ouspenski I, Brinkley BR \& May GS 1998 The cenpB gene is not essential in mice. Chromosoma 107 570-576.

Kipling D \& Warburton PE 1997 Centromeres, CENP-B and Tigger too. Trends in Genetics 13 141-144.

Lee HW, Blasco MA, Gottlieb GJ, Horner 2nd JW, Greider CW \& DePinho RA 1998 Essential role of mouse telomerase in highly proliferative organs. Nature 392 569-574.

Lincoln AJ, Wickramasinghe D, Stein P, Schultz RM, Palko ME, De Miguel MP, Tessarollo L \& Donovan PJ 2002 Cdc25b phosphatase is required for resumption of meiosis during oocyte maturation. Nature Genetics 30 446-449.

Lock LF, Wickramasinghe D, Ernst MK, Gilbert DJ, Copeland NG, Jenkins NA \& Donovan PJ 1996 The Cdc25 genes map to mouse chromosomes 2, 9, and 18. Mammalian Genome 7 $771-772$.

Maney T, Ginkel LM, Hunter AW \& Wordeman L 1999 The kinetochore of higher eucaryotes: a molecular view. International Review of Cytology 194 67-131.

Moll R, Franke WW, Schiller DL \& Gieger B 1982 The catalog of human cytokeratins: patterns of expression in normal epithelia, tumours and cultured cells. Cell 3 111-124.

Mutant mice and neuroscience: recommendations concerning genetic background. Banbury Conference on genetic background in mice.

Perez-Castro AV, Shamanski FL, Meneses JJ, Lovato TL, Vogel KG, Moyzis RK \& Pedersen R 1998 Centromeric protein b null mice are viable with no apparent abnormalities. Developmental Biology 201 135-143.

Saffery R, Earle E, Irvine DV, Kalitsis P \& Choo KHA 1999 Conservation of centromere proteins in vertebrates. Chromosome Research $7261-265$.

Sullivan KF \& Glass CA 1991 CENP-B is a highly conserved mammalian centromere protein with homology to the helix-loop-helix family of proteins. Chromosoma $100360-370$.

Sunkel CE \& Coelho PA 1995 The elusive centromere: sequence diversion and functional conservation. Current Opinion in Genetics and Development 5 756-767.

Sztein JM, Sweet H, Farley JS \& Mobraaten LE 1998 Cryopreservation and orthotopic transplantation of mouse ovaries: new approach in gamete banking. Biology of Reproduction $\mathbf{5 8}$ 1071-1074.

Threadgill DW, Dlugosz AA, Hansen LA, Tennenbaum T, Lichti U, Yee D, LaMantia C, Mourton T, Herrup K, Harris RC, Barnard JA, Yuspa SH, Coffey RJ \& Magnuson T 1995 Targeted disruption of mouse EGF receptor: effect of genetic background on mutant phenotype. Science 269 230-234.

Tomascik-Cheeseman L, Marchetti F, Lowe X, Shamanski FL, Nath J, Pedersen RA \& Wyrobek AJ 2002 CENP-B is not critical for meiotic chromosome segregation in male mice. Mutation Research 513 197-203.

Uren AG, Wong L, Pakusch M, Fowler KJ, Burrows FJ, Vaux DL \& Choo KHA 2000 Survivin localises to the centromere, and Survivin gene-disrupted mice show a mitotic defect resembling the Incenp null phenotype. Current Biology 10 1319-1328.

Yoda K, Kitagawa K, Masumoto H, Muro Y \& Okazaki T 1992 A human centromere protein, CENP-B, has DNA binding domain containing four potential alpha helices at the $\mathrm{NH}_{2}$-terminus, which is separable from dimerizing activity. Journal of Cellular Biology 119 1413-1427.

Received 10 September 2003

First decision 23 October 2003

Accepted 19 November 2003 